\title{
Access Routes of Internet Finance Dictionaries: Present Solutions and Future Opportunities
}

Deny Arnos Kwary, Centre for Lexicography, Aarhus School of Business, Aarhus University, Aarhus, Denmark (deak@asb.dk)

\begin{abstract}
Lexicographers working on finance dictionaries have not properly exploited the fast development of the Internet. This is revealed by the poor utilization of the access routes found in current Internet finance dictionaries. Consequently, users cannot effectively and efficiently find answers to their lexicographical problems. Firstly, there are Internet finance dictionaries which lack technological features and can simply be called meagre Internet dictionaries. Secondly, there are Internet finance dictionaries which utilize so many technological features that users incur high lexicographical information costs. In order to create better access routes, a sound theoretical foundation has to be established. This article shows that the implementation of the modern theory of lexicographical functions, which focuses on the users, results in a better design for future Internet finance dictionaries. With the proper theoretical basis, lexicographers will be able to create state-ofthe-art dictionaries that can provide effective and efficient solutions to lexicographical problems.
\end{abstract}

Keywords: DICTIONARY, PAPER DICTIONARY, INTERNET DICTIONARY, LSP DICTIONARY, FINANCE DICTIONARY, FINANCIAL TERMS, LEXICOGRAPHY, LEXICOGRAPHICAL FUNCTIONS, TEXT RECEPTION, USER NEEDS, USER SITUATION, ACCESS ROUTES, SEARCH OPTIONS, LEXICOGRAPHICAL INFORMATION COSTS

Opsomming: Toegangsroetes van Internet- finansiële woordeboeke: Huidige oplossings en toekomstige geleenthede. Leksikograwe wat aan finansiële woordeboeke werk, het nie die vinnige ontwikkeling van die Internet behoorlik benut nie. Dit blyk uit die gebrekkige aanwending van die toegangsroetes wat in huidige Internet- finansiële woordeboeke aangetref word. Gevolglik kan gebruikers nie doeltreffend en doelmatig antwoorde kry op hul leksikografiese probleme nie. Eerstens is daar Internet- finansiële woordeboeke waarin tegnologiese kenmerke ontbreek en wat gewoon karige Internetwoordeboeke genoem kan word. Tweedens is daar Internet- finansiële woordeboeke wat so baie tegnologiese kenmerke aanwend dat gebruikers hoë leksikografiese inligtingskoste oploop. Om beter toegangsroetes te skep, moet 'n deeglike teoretiese grondslag gevestig word. Hierdie artikel toon dat die toepassing van die moderne teorie van leksikografiese funksies wat op die gebruikers fokus, lei tot 'n beter ontwerp vir toekomstige Internet- finansiële woordeboeke. Met die gepaste teoretiese basis, sal leksikograwe in staat wees om woordeboeke te skep wat die jongste tegnologie gebruik om doeltreffende en doelmatige oplossings vir leksikografiese probleme te bied.

Sleutelwoorde: WOORDEBOEK, PAPIERWOORDEBOEK, INTERNETWOORDEBOEK, TSD-WOORDEBOEK, FINANSIËLE WOORDEBOEK, FINANSIËLE TERME, LEKSIKOGRAFIE, LEKSIKOGRAFIESE FUNKSIES, TEKSONTVANGS, GEBRUIKERSBEHOEFTES, GEBRUIKERSITUASIE, TOEGANGSROETES, SOEKKEUSES, LEKSIKOGRAFIESE INLIGTINGSKOSTE 


\section{Introduction}

Recent advances in Internet technology offer numerous features which can be incorporated into Internet dictionaries. However, these advances have not been properly embraced by lexicographers. Nielsen and Mourier (2005: 110) noted that some Internet dictionaries are based on printed dictionaries and not developed directly for the electronic medium. They therefore do not take advantage of the features offered by Internet technology. Some other Internet dictionaries may have been developed directly for the electronic medium, but the lack of a sound theory which focuses on user needs has made these dictionaries incapable of thoroughly and swiftly satisfying the needs of the users.

A clear example of the poor response to the technology and user needs is the utilization of access routes. The access routes offered by the current Internet Finance Dictionaries (IFDs) are either ineffective or inefficient in helping users find what they are looking for. The search options, which should provide the quickest access route to reach a result, are not efficiently designed. In addition, the results given are not effective in helping the users to understand the terms they are looking for. Consequently, a better concept for the access routes of Internet finance dictionaries is needed, and, as De Schryver (2003: 188) states, a sound underlying theory is obviously needed in creating future electronic or Internet dictionaries.

\section{Theoretical Foundation}

In order to improve the quality of IFDs, users should become the point of departure in creating the dictionary. This is in line with Bogaards (1999: 118) who urges lexicographers 'to adopt more often and more systematically the viewpoint of the learner' or the dictionary users. In addition, sound theoretical foundations should also be taken into account. In this case, the modern theory of lexicographical functions proposed by Tarp (2008) is applied as it focuses on the users. The concept of lexicographical information costs proposed by Nielsen (2008) is also employed so that the solutions are based not only on the availability of the technological features but also on the calculation of the lexicographical information costs.

The concept of lexicographical information costs was initially proposed by Nielsen (1999). In a later article, Nielsen (2008) divides lexicographical information costs into two distinct types: search-related information costs (SRIC) and comprehension-related information costs (CRIC). SRIC are 'the costs (i.e. efforts) related to the look-up acts users have to perform when consulting a dictionary in order to gain the data for which they are searching', whereas CRIC are 'the costs (i.e. efforts) related to the user's ability to understand and interpret the data presented in the dictionary' (Nielsen 2008: 173-174). Both the SRIC and CRIC are indispensable, as shown in the following sections, for examining the current Internet finance dictionaries and for proposing better search options. 


\section{Examining Present Solutions of Current Internet Finance Dictionaries}

The current Internet finance dictionaries contain disproportionate numbers of technological features; some of them use too few features while others provide too many features. Therefore, they can generally be categorized into two groups: meagre Internet dictionaries and extravagant Internet dictionaries. Meagre Internet dictionaries are Internet dictionaries that utilize so few technological features that they result in poor quality technological capabilities, whereas extravagant Internet dictionaries are those that use technological features in such a careless way that these become wasteful.

\subsection{Meagre Internet Dictionaries}

There are two typical examples of Internet finance dictionaries which can be categorized as meagre Internet dictionaries. The first one is the Internet version of the paper dictionary entitled The Language of Money by Carew (1996). The other is the Internet version of the paper dictionary entitled The New York Times Dictionary of Money and Investing by Morgenson and Harvey (2002). The Internet version of The Language of Money can be found in the website of ANZ Bank. It appears to be part of the ANZ financial literacy program, called MoneyMinded, which comprises educational resources for people in need of financial education. The Internet version of The New York Times Dictionary of Money and Investing is available at Duke University, where one of the authors, Harvey, is Professor of International Business.

Figure 1: Web Page of the Internet Version of The Language of Money

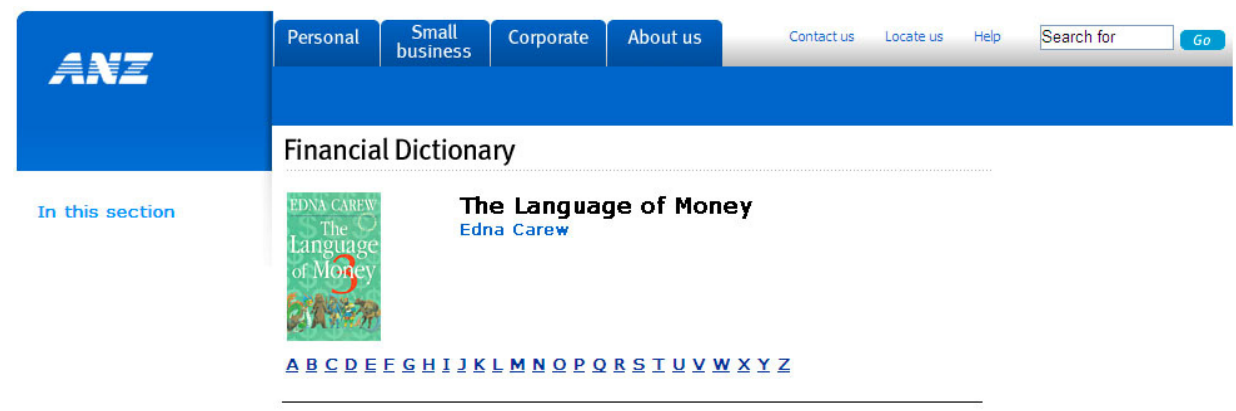

C Copyright Australia and New Zealand Banking Group Limited 100 Queen street, Melbourne 3000 (ABN 11 005 357 522), 1996-2009. ANZ's colour blue is a trade mark of ANZ. Any advice does not take into account your personal needs and financial circumstances and you should consider whether it is appropriate for you . ANZ recommends you read the Product Disclosure Statement and the Financial Services Guide before acquiring the product.

When opening the website of The Language of Money, users are presented with a picture of the cover of the printed dictionary and an alphabetical list of the dictionary entries, as shown in Figure 1. The search text-box (marked 'Search for') 
and the search button (marked 'Go') on the right-hand top are not for searching the terms available in the dictionary, but for searching through the website of ANZ bank. Therefore, when using this dictionary, users cannot type in the term they are looking for.

When users are presented with a web page like this, their look-up acts have to be similar to those for paper dictionaries. For example, if users want to find the definition of the term debenture, they need to click the letter $\mathrm{D}$, and then a new web page will pop up, listing all the entries under the letter D. This is shown in Figure 2. Owing to the standard size of the computer screen, only the first few entries under the letter D can be shown on the screen. Therefore, users have to scroll down the screen to find the term debenture they are looking for, because it is not on top of the list.

Figure 2: Web Page of Entries under the Letter D of The Language of Money

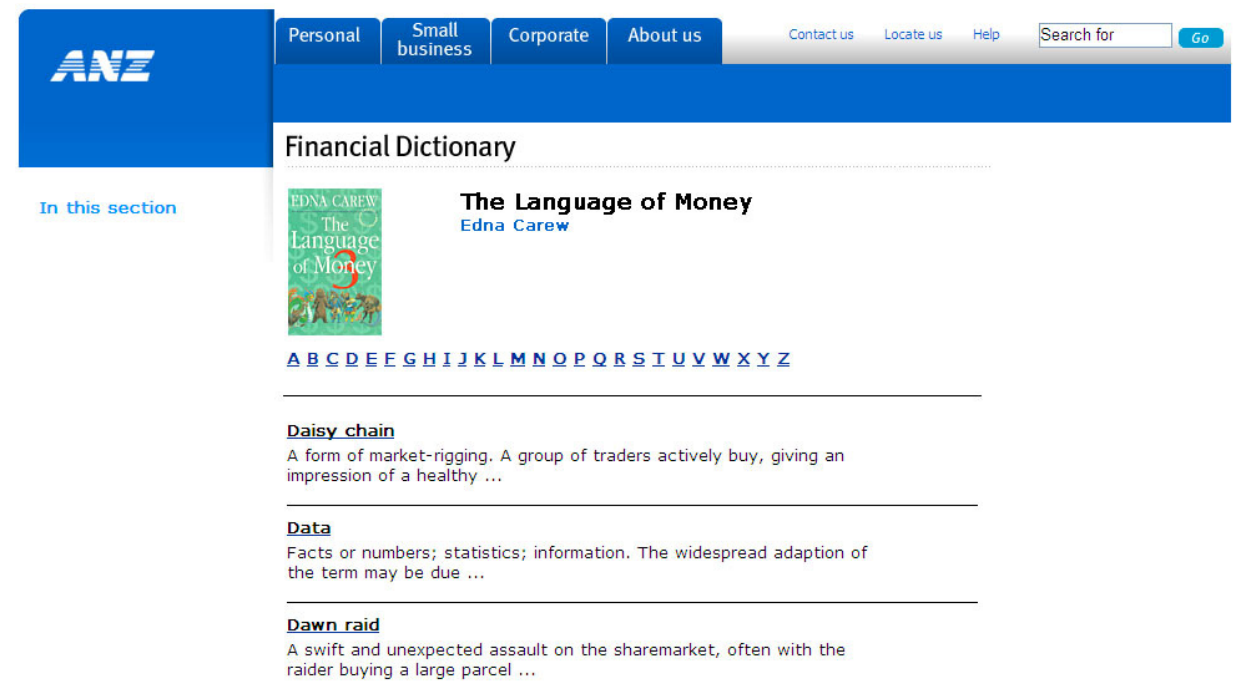

After having scrolled down the screen, users finally find the term they are looking for. However, the look-up acts have not finished, because the definition presented for the term is not complete. It seems that the designer of the Internet version of this dictionary wanted to shorten the length of the page, so only the first two lines of the definition are presented for each entry word. Dictionary users still have to click the entry word to see the complete definition. Consequently, users need to perform at least four look-up acts to reach the dictionary article they are looking for. This certainly takes too much time. In addition, there is no quick link from a term found in the definition to its dictionary entry. Users have to start all over again to find the definition of a term used within the definition and which they do not understand. This dictionary barely utilizes available technological features, so it can simply be called a meagre Internet dictionary. 
The second dictionary, The New York Times Dictionary of Money and Investing, provides quick links from the terms found in the definitions to their dictionary articles. However, the access routes to the dictionary articles are still similar to the printed version of the dictionary. Therefore, it can be categorized as a meagre Internet dictionary. As Figure 3 shows, users cannot type in the term they are looking for, because the web page has no text-box and search button. The web page only shows the cover of the printed dictionary and an alphabetical list of the dictionary entries.

Figure 3: Web Page of the Internet Version of The New York Times Dictionary of Money and Investing

\section{Campbell R. Harvey's Hypertextual Finance Glossary}

Over 8,000 Entries and 18,000 Hyperlinks

The largest financial glossary on the Internet

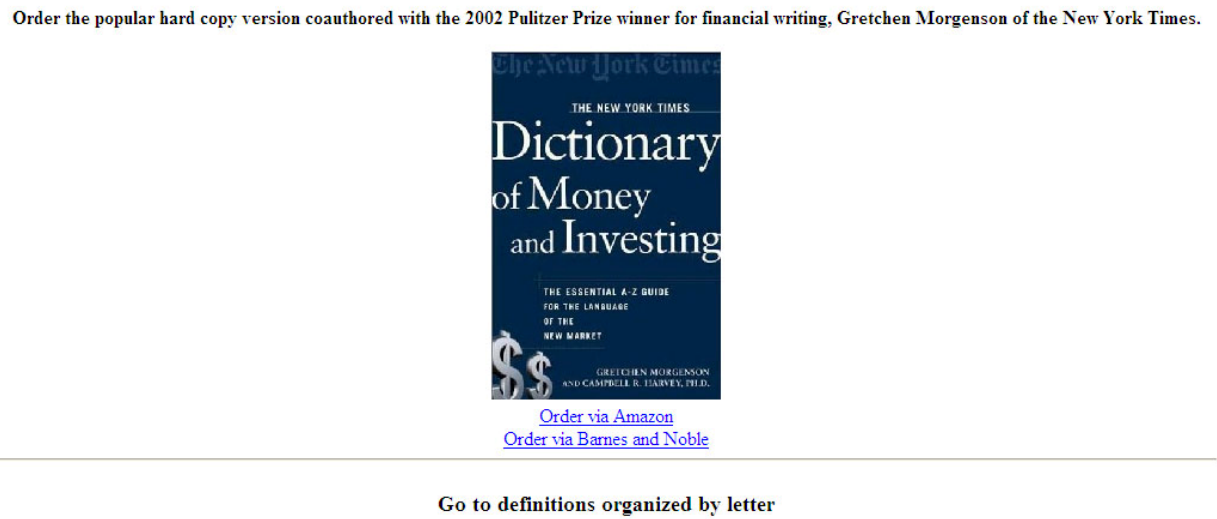

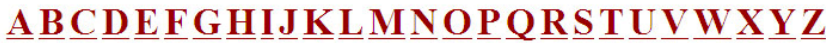

To reach a dictionary article, users will have to follow access routes that are similar to those for paper dictionaries. Using the previous example to find the definition of the term debenture, users must click on the letter D and another web page will pop up, as shown in Figure 4 . The web page presents all the entries for the letter $D$, but the size of the computer screen prevents users from directly seeing the entry for debenture. Users have to scroll down the screen to find the term they are searching for.

The only difference between this dictionary and the first is the presentation of the dictionary articles. In the first dictionary, only the first two lines of the definition are presented for each dictionary entry, so users still have to click the entry to see the complete definition. In the second dictionary, users are directly presented with the complete definition. Therefore, instead of perform- 
ing four look-up acts, it will only take three look-up acts to reach the dictionary article users are looking for.

Figure 4: Web Page of Entries under the Letter D of The New York Times Dictionary of Money and Investing

\section{Campbell R. Harvey's Hypertextual Finance Glossary}

Copyright @ 2009. All Worldwide Rights Reserved. Do not reproduce without explicit permission.

Order the popular hard copy version coauthored with the 2002 Pulitzer Prize winner for financial writing,

Gretchen Morgenson of the New York Times.

Order via Amazon

Order via Barnes and Noble

Featured Links

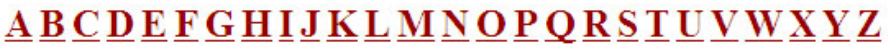

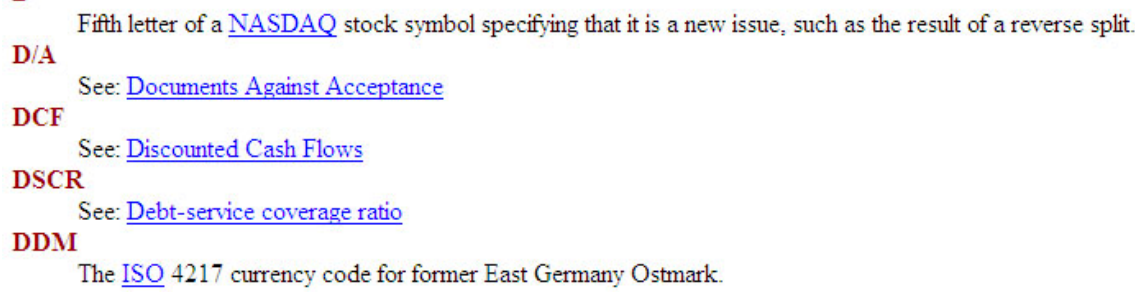

As becomes clear from the above description, these two Internet dictionaries can undoubtedly be called meagre Internet dictionaries. As shown in the access process to the dictionary entries, both of them use only very few technological features for the Internet versions of the dictionaries. This results in high searchrelated information costs, as users have to perform at least three look-up acts when consulting these dictionaries in order to arrive at the data they are searching for.

\subsection{Extravagant Internet Dictionaries}

As explained above, there are Internet finance dictionaries which utilize too few technological features. In contrast, other Internet finance dictionaries use too many technological features, which are carelessly presented. These finance dictionaries can be called extravagant Internet dictionaries. Two examples of this type of Internet finance dictionaries are www.investopedia.com/dictionary/default.asp, which is provided by Forbes Digital Company, and www.financial-dictionary.thefreedictionary.com, which is managed by Farlex. 
When opening the website, www.investopedia.com/dictionary/default.asp, users are presented with three options to search for a term, i.e. 'By Keyword' (a text-box with a search button), 'By Alphabet', and 'By Category'. There is also information about 'Top 10 Searched Terms' and 'Recently Added Terms' (see Figure 5).

Figure 5: Web Page of www.investopedia.com/dictionary/default.asp

\section{Financial Dictionary}

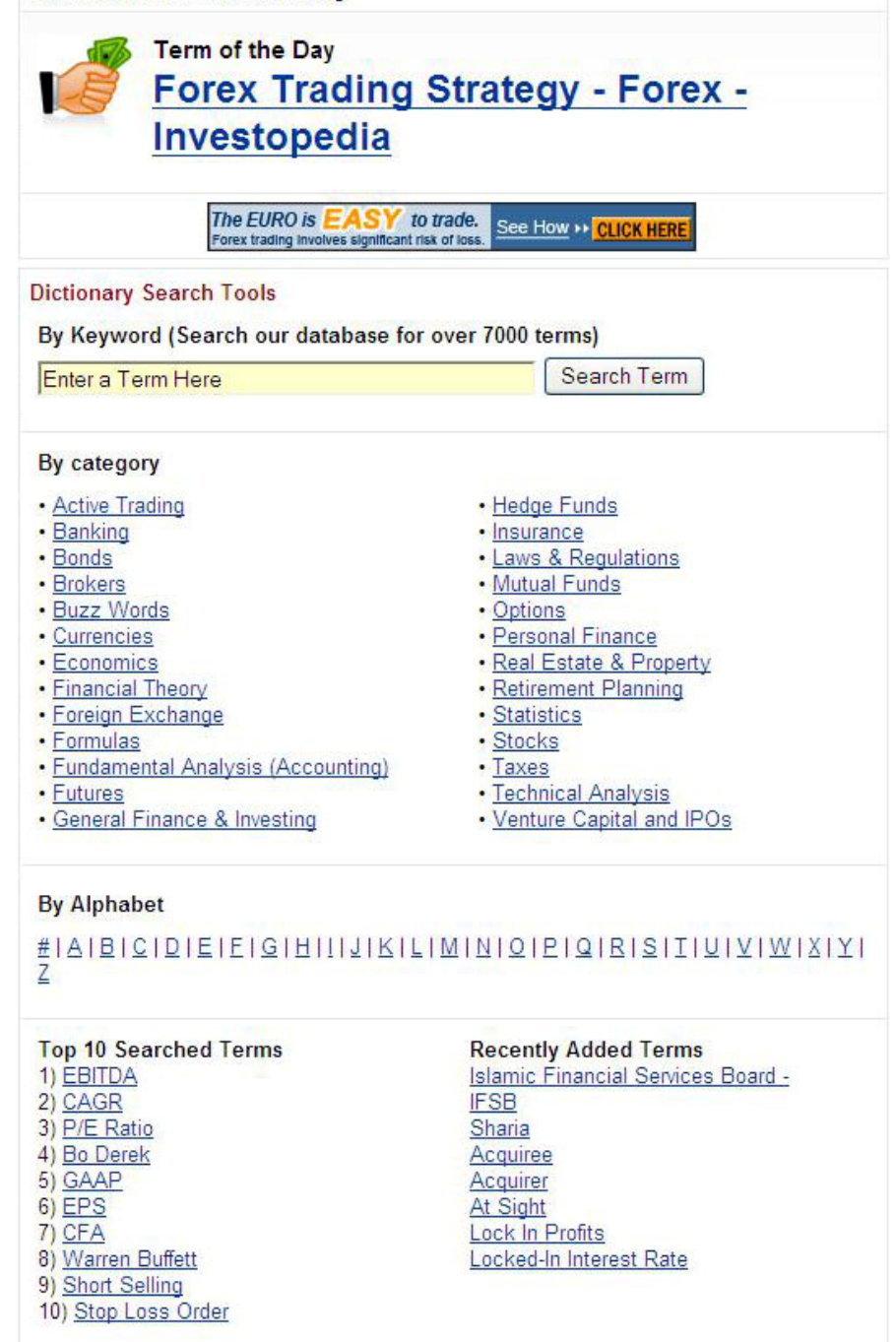

From these menus, it can reasonably be assumed that the 'By Keyword' menu is the one most commonly used, because Internet dictionary users, who are also 
Internet users, are used to typing a word into a text-box when searching the Internet for information. However, when this 'By Keyword' menu is used, it will become apparent that the lexicographical information costs incurred are high. For instance, after typing the term debenture and clicking the search button, users are directed to another web page (see Figure 6) which presents a list of dictionary terms (links) related to the term debenture. Users need to click one of the links to see the relevant definition. Therefore, the search-related information costs (SRIC) are high because users have to perform two look-up acts instead of just one to find a definition. The technology enables the website to present results of related terms, but it is not the first information users need when consulting a dictionary to search for definitions of the terms.

Figure 6: Search Results from www.investopedia.com/dictionary/default.asp

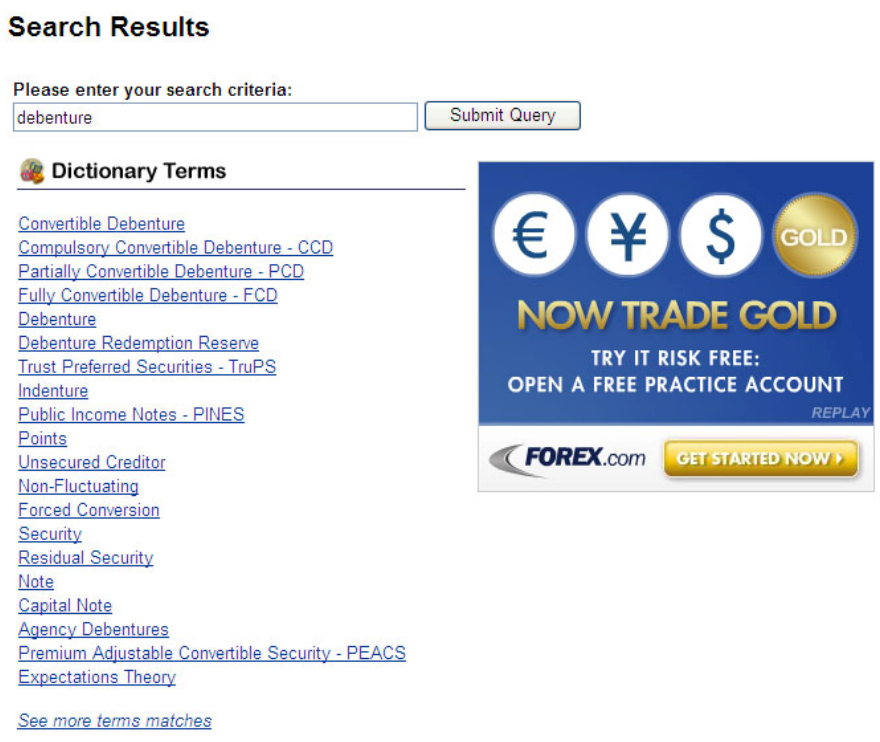

In the definition itself, users are still faced with high comprehension-related information costs (CRIC), because of the lengthy article and the difficult words without any cross-references to other dictionary articles. The definition of the term debenture given in this dictionary reads as follows:

\section{Debenture}

A type of debt instrument that is not secured by physical asset or collateral. Debentures are backed only by the general creditworthiness and reputation of the issuer. Both corporations and governments frequently issue this type of bond in order to secure capital. Like other types of bonds, debentures are documented in an indenture.

Terms in the definition, like collateral and indenture, may cause a comprehension problem to users. In addition, since there are no cross-reference links to 
these terms, users have to type these terms again in the text-box to find the definitions instead of simply clicking the terms. Consequently, both the CRIC and SRIC incurred are high. On the one hand, this dictionary has used the Internet technological features in the design by providing three options to search for a term and also information about 'Top 10 Searched Terms' and 'Recently Added Terms'. On the other hand, the technological features used are not really helpful for users, only leading to high lexicographical information costs.

Figure 7: Web Page of www.financial-dictionary.thefreedictionary.com

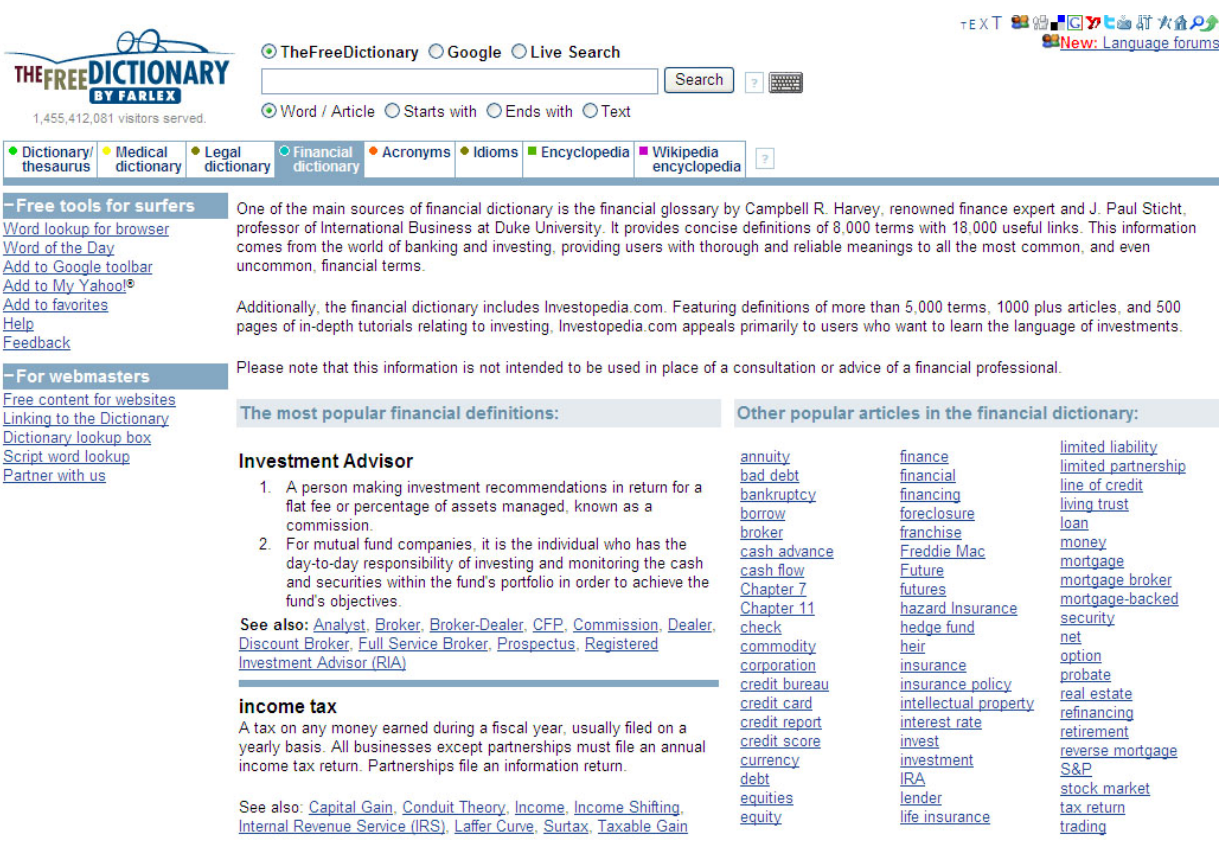

The second dictionary, www.financial-dictionary.thefreedictionary.com, also contains some technological features. However, the lexicographical information costs incurred are still high. The first web page of this dictionary, as shown in Figure 7, presents a text-box with four radio-buttons which enable users to search for Word/Article, Starts with, Ends with, and Text. There are also two menus: 'The most popular financial definitions' and 'Other popular articles in the financial dictionary'. These two menus, however, are not very useful for dictionary users. It is unlikely that anyone will open a dictionary in order to find the most popular definitions or popular articles. Moreover, these additional menus may distract dictionary users from their main purpose of consulting the dictionary, i.e. finding the definition of a term.

On the right-hand side of the text-box, there is an icon which looks like a small keyboard. When users click this icon, a virtual keyboard will pop up and users can click on the buttons on the virtual keyboard to type a term into the 
text-box. For instance, when users want to search for the term debenture, they can either click on the text-box and type the word or click the keyboard icon and click each letter. A test reveals that it takes more time to click each letter from the virtual keyboard than to type the word directly. Therefore, this technological feature is not really useful.

After a term, e.g. debenture, has been searched for, it becomes apparent that this dictionary utilizes the technological features excessively, which results in high lexicographical information costs. The search result for debenture (Figure 8) shows four definitions, taken from four different dictionaries. This results in high CRIC because users will firstly have to read all four definitions and secondly will not know how to choose the best one. Therefore, the technology, which enables the website to present results from several dictionaries at once only confuses users.

Figure 8: Search Results from www.financial-dictionary.thefreedictionary.com

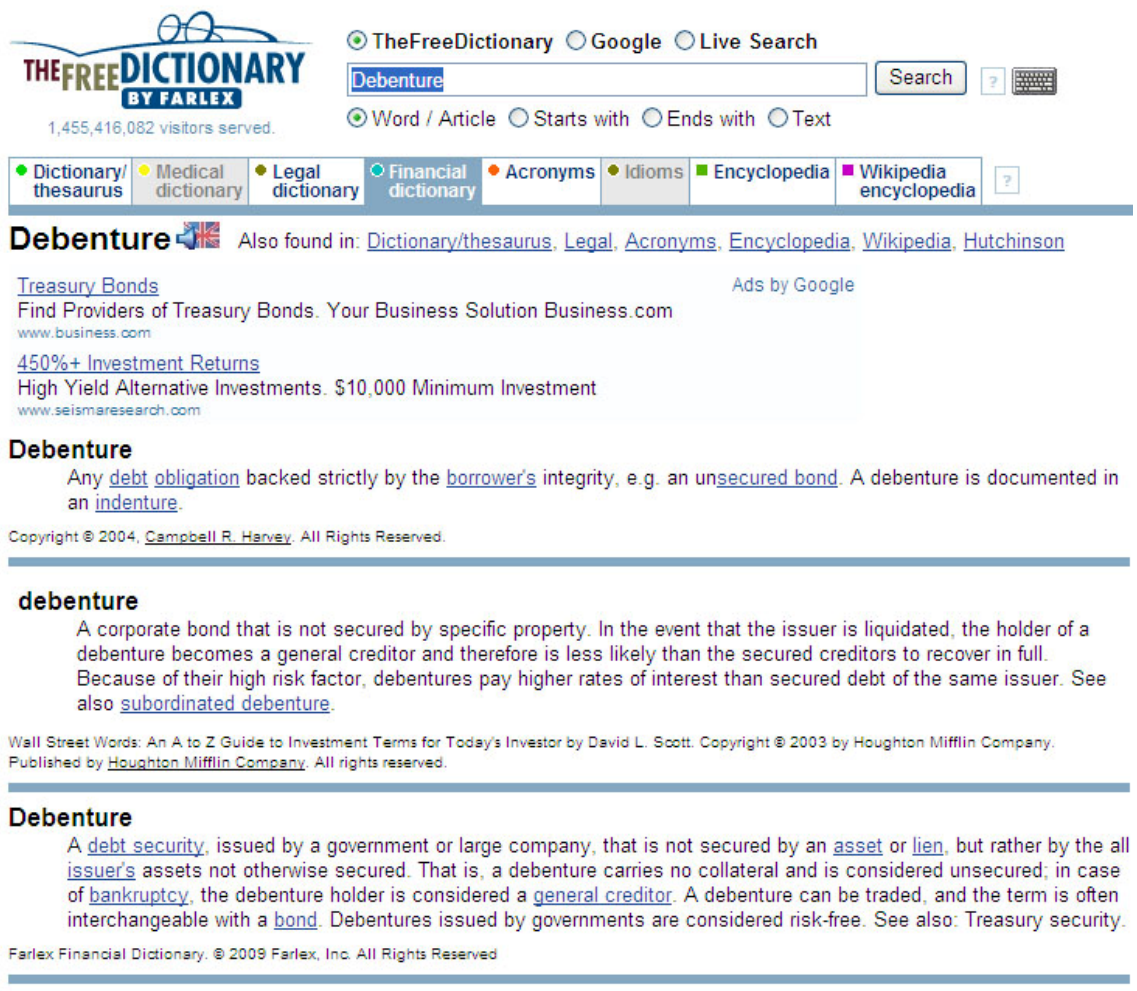

Debenture. A debenture is an unsecured bond. Most bonds issued by corporations are debentures, which are backed by their reputation rather than by any collateral, such as the company's buildings or its inventory.

Although debentures sound riskier than secured bonds, they aren't when they're issued by well-established companies with good credit ratings 
From the discussion above, it is clear that the search options provided in these dictionaries do not really help users find what they are looking for in the shortest time and in the most comprehensible way. Therefore, it is necessary in the future to create Internet finance dictionaries with better lexicographical solutions so that the needs of dictionary users can be properly satisfied.

\section{Future Opportunities for Internet Finance Dictionaries}

In order to create a dictionary which can satisfy the needs of users properly, it is necessary to focus on its function and the intended users. By focusing on a particular function, lexicographers will be able to provide better solutions to satisfy the predetermined function. This is not to say that IFDs must only have one function, but it is better to work on one function at a time during the design and development phases. In addition, focusing on a particular user group may also result in better IFDs, because the lexicographical solutions provided can be tailored to the competences of the particular user group.

\subsection{Focusing on a Particular Function}

In focusing on a particular function, the modern theory of lexicographical functions initially proposed by Tarp (1994) can be used as it emphasizes the functions of a dictionary as the point of departure in creating the dictionary. A lexicographical function is 'the efforts and ability of a dictionary to provide answers to the complex needs arising in a user in a specific usage situation' (Tarp 1998: 123). As the name of the theory suggests, the first step in creating a dictionary concept is to determine the function of the dictionary for the user group. For communicative oriented functions, according to Bergenholtz and Tarp (2003: 176), a dictionary can be used to assist users in solving problems related to:

(a) text reception in the native language,

(b) text production in the native language,

(c) text reception in a foreign language,

(d) text production in a foreign language,

(e) translation of texts from the native language into a foreign language, and

(f) translation of texts from a foreign language into the native language.

In the case of dictionaries of English financial terms for non-native speakers of English, it is the third out of these six functions which is mostly sought. It is more common for learners, who are LSP dictionary users, to read than to write or translate L2 LSP texts. Because their learning materials usually comprise L2 
texts, they will need to read and understand the L2 text. However, they will not be asked to translate the texts, neither to write the assignments in L2. Therefore, the most important function in this case is text reception in a foreign language. With this function concept in mind, a possible design for an Internet finance dictionary can be created, as shown in Figure 9.

Figure 9: Design of an Internet Finance Dictionary Focusing on a Particular Function

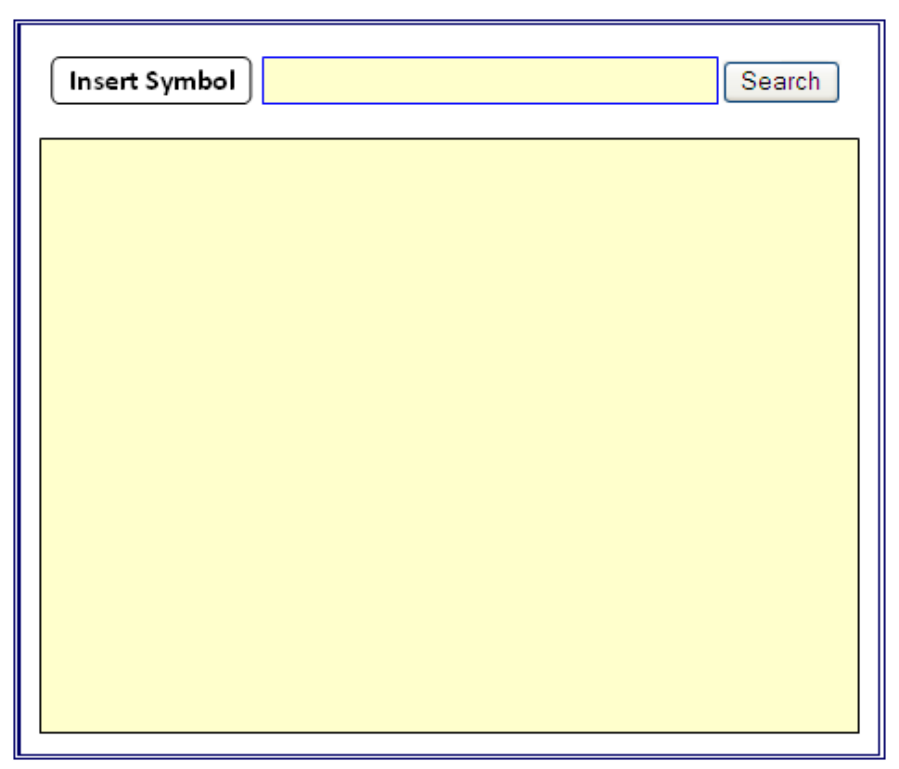

The Internet finance dictionary has four items, i.e. a text-box, a search button, a search result box, and an insert symbol icon. The text-box is used to type the term, and the search button is used to execute the search. Then, the result is shown in the search result box on the web page. Users should not be directed to another web page or to a list of related terms as in www.investopedia.com/ dictionary/default.asp, because users do not need such information. What they need is the dictionary article or the definition of the term. In addition, the dictionary should only present a single definition rather than four definitions from four different dictionaries as in www.financial-dictionary.thefreedictionary. com, so that users will not spend too much time reading the different definitions and be confused about choosing the right one.

In a text reception situation, users encounter a term which they do not understand and they consult the dictionary to find the meaning of the term. They exactly know the spelling of the term as they are reading it, so they can just type the term into the text-box. A problem in typing the term occurs when the term is not in Roman spelling, for instance, terms like $\beta$ ('market risk') and $\mu$ ('population mean') which are quite common in financial texts. It is impossible 
for users to type them as these characters are not on the computer keyboard. Therefore, an insert symbol icon should be provided. When users click this icon, a virtual keyboard will pop up, listing the common symbols found in financial texts. Users can click the relevant symbol and it will be directly inserted into the text-box, so that users can search for its meaning.

Other options, such as 'Top 10 Searched Terms', 'Recently Added Terms', 'The most popular financial definitions' and 'Other popular articles in the financial dictionary', offered in the dictionaries examined in the previous section, are not only unnecessary but also clutter the computer screen and distract users from finding the solutions to their problems in the fastest way. The simple Internet dictionary design shown in Figure 9 better provides the solutions to text reception problems than the complicated designs shown in Figures 5 and 7, since in this simple design, the lexicographical information costs incurred are lower. The SRIC is lower because users are shown the result directly after they have clicked the Search Button, and the CRIC is also lower because the results are not based on a compilation of definitions from several dictionaries.

\subsection{Focusing on a Particular User Group}

A further step which can be taken after determining the function of the dictionary considers the main elements included in the function concept. There are four main elements of lexicographical functions: types of potential user, user situation, user need, and assistance to meet the needs (Tarp 2008: 43). Determining those elements will result in a more focused dictionary with better solutions to lexicographical problems of a particular user group. To see how these elements are implemented in a dictionary project, this article takes the example of the on-going project on the English Dictionary of Finance for Indonesian CFA (Chartered Financial Analysts) Candidates. However, the solutions proposed on the access routes may also be applicable to other LSP dictionaries with similar types of users.

For this dictionary, the potential users are Indonesians who have completed undergraduate programs from a faculty of economics or a school of business and are preparing to take the CFA examinations. To draw up a more specific profile of this intended user group, the following eight characteristics proposed by Bergenholtz and Nielsen (2006: 285-286) can be considered:

(a) Which language is their native language?

(b) At what level do they master their native language?

(c) At what level do they master a foreign language?

(d) How extensive is their experience in translating between the languages in question?

(e) What is the level of their general cultural and encyclopaedic knowledge? 
(f) At what level do they master the special subject field in question?

(g) At what level do they master the corresponding LSP in their native language?

(h) At what level do they master the corresponding LSP in the foreign language?

Since the function of the dictionary is to assist in text reception, characteristics (d) and (e) can be disregarded, because they refer to translation experience and a cognitive function respectively. Consequently, for this dictionary, the user profile is as follows:

(a) Their native language is Indonesian, because they are Indonesians.

(b) They master Indonesian at an advanced level, because they are students who have studied up to undergraduate level in Indonesia.

(c) They master English at an intermediate level, because they have studied English for at least seven years.

(d) They are semi-experts in finance, because they have completed an undergraduate program where they have taken several courses related to finance.

(e) They master Indonesian financial terminology at an intermediate level, because they have learned some financial terms in Indonesian during their undergraduate program.

(f) They master English financial terminology at a basic level, because they rarely encountered English financial terms during their undergraduate program.

The user situation relevant for this dictionary is reading American financial texts, mainly from the CFA Institute. Therefore, the primary need of the intended user group is help to understand the texts they read, especially when they find terms of which they do not know the meaning. Since they are reading the texts in the framework of preparing for the CFA examinations, the secondary need of these users is help to answer the CFA examination questions. After having determined the potential users, user situation, and user needs, assistance to satisfy the needs can be provided, as shown in Figure 10.

The design features nine items: a text-box, a search button, a search result box, an insert symbol icon, a financial calculator icon, and four checkboxes. The functions of the text-box, the search button, the search result box and the insert symbol icon are the same as those explained for Figure 9. In addition, four further search options are provided. These search options are designed with checkboxes so that users can, if they like, choose more than one option. The first checkbox is for 'Indonesian equivalent' which is also the default option. 
When users click the search button directly after having typed in the English term, only the Indonesian equivalent of the English term is presented in the search result box. According to Bergenholtz and Johnsen (2007: 10), 'if a user wants to understand a word, showing only the equivalent is adequate'. For this reason the Indonesian equivalent has been set as the default option. Moreover, since the users are semi-experts in finance, master Indonesian financial terminology at an intermediate level, and master English financial terminology at a basic level, providing the Indonesian equivalent is the best option as it will lead to the lowest CRIC in most cases.

Figure 10: Design of an Internet Finance Dictionary Focusing on a Particular User Group

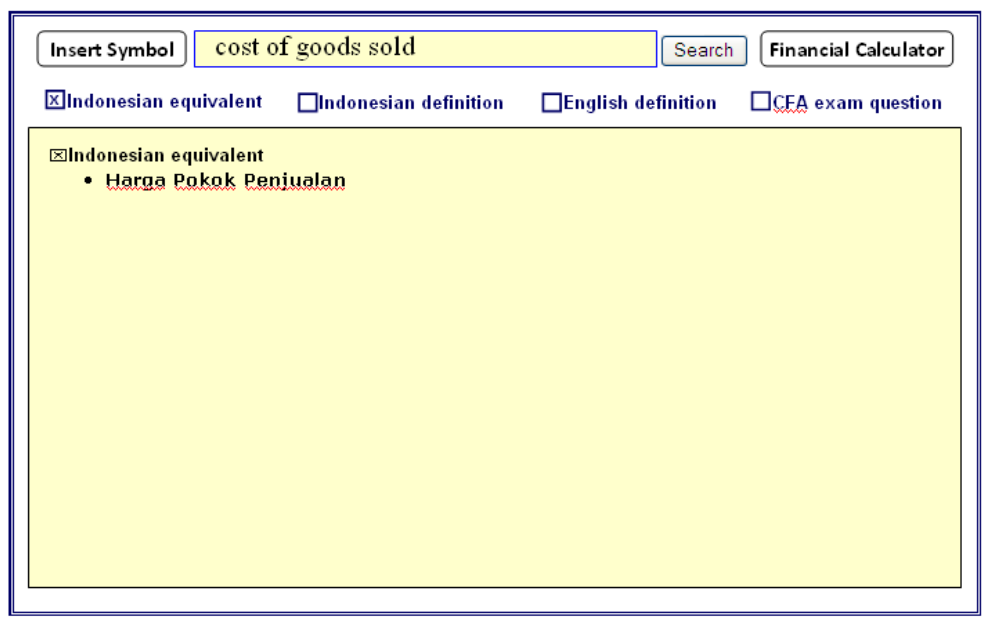

The second checkbox is for 'Indonesian definition', so when users tick this box, the Indonesian definition of the English term will be presented in the search result box. This option is useful when the Indonesian equivalents are only a transfer of the English spelling to the Indonesian spelling patterns. For example, the Indonesian equivalent of the English term debenture is debentur. Both of these are incomprehensible to the users, so they need a further explanation which can be provided from the checkbox for 'Indonesian definition'. It is also sensible to put this checkbox as the second option before the checkbox for 'English definition', because the users have mastered Indonesian at an advanced level, and English only at an intermediate level. The CRIC incurred will be lower for 'Indonesian definition' than for 'English definition'.

In some situations, there are users in this group who may choose the 'English definition' because they would like to see how the term is defined in English or because they want to practise their English. This is sensible because they are also in the situation of preparing to take the CFA examination which is in English. Hence, a checkbox for 'English definition' is also given in this dic- 
tionary. Furthermore, considering that "financial jargon uses a great many acronyms and abbreviations" (Carew 1996: vii), the option 'English definition' can also be the place to put the extension of acronyms and abbreviations, together with their definitions as necessary.

The fourth option, a checkbox for 'CFA exam question' is provided together with a financial calculator icon, which will be useful when users want to see how the term is used in the examination and want to answer a sample of examination questions. However, since the users have mastered English at an intermediate level and have mastered English financial terminology at a basic level, it is necessary to provide a quick reference to the difficult words in the 'English definition' and 'CFA exam question'. For instance, as can be seen in Figure 11, when the word or the term in the search result box is clicked, a 'call out' will pop up and show the 'Indonesian equivalent' of the term. Therefore, users do not need to type the term again in the text-box to find the definition. The 'call out' option provides access with low SRIC.

Figure 11: Internet Finance Dictionary Showing Two Search Results

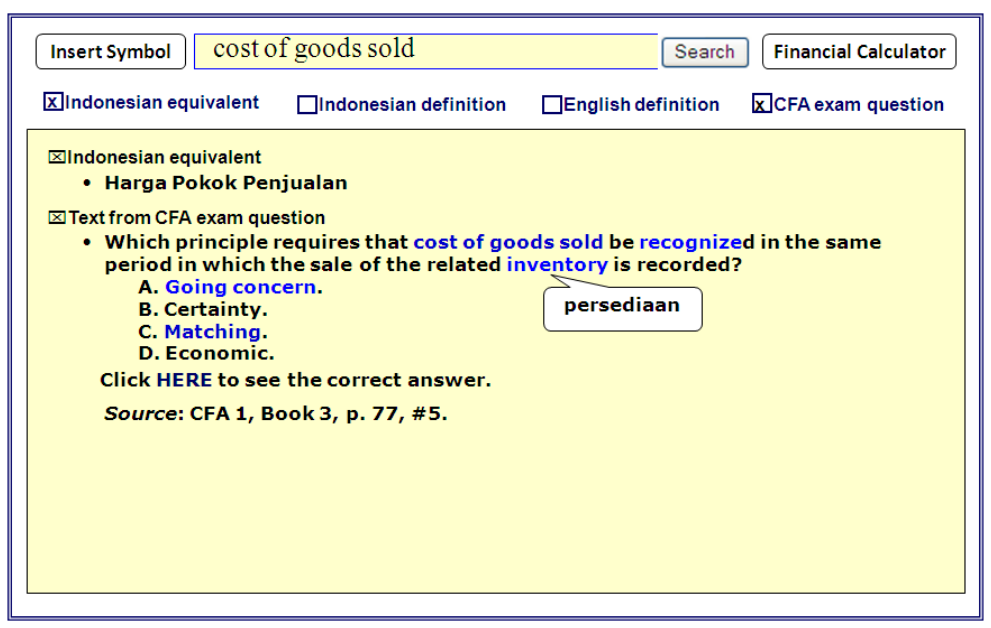

There are two checkboxes chosen in Figure 11, i.e. 'Indonesian equivalent' and 'CFA exam question'. This is an example of a situation where a user has a problem in comprehending a term like cost of goods sold. The user starts by typing the term into the text box and clicking the Search button or pressing the Enter button in the keyboard, and he is directly presented with the Indonesian equivalent of the term. Then, if he wants to know how this term is used in an examination, he clicks the checkbox 'CFA exam question' and an example of an examination question is immediately shown below the Indonesian equivalent.

Although there are two results shown in Figure 11 for the term cost of goods sold, it does not mean that the CRIC will be high. In this case, the capability of the technology to present more than one result is utilized well. It is different from www.financial-dictionary.thefreedictionary.com (Figure 7), which 
presents definitions from several dictionaries at once. The first difference is that in the design in Figure 7, users cannot choose whether they want to see just one definition or more than one, whereas the design in Figure 11 allows users to choose the data to be presented. The second difference is that the design in Figure 7 presents several definitions and users may not know which one they should follow and which ones are redundant, whereas the design in Figure 11 presents two sets of data which are mutually beneficial, since the first one is the equivalent, which enables users to understand the term, and the second one is an example from the examination which shows the term in actual use. Consequently, this dictionary design meets both the primary and the secondary needs of the users.

The above discussion clearly illustrates that, by knowing the users well, lexicographers are able to create dictionaries that give users what they need (Atkins and Rundell 2008: 28). More importantly, the data presented at any given time or look up fits in with the needs of a particular user in a given user situation (Andersen and Nielsen 2009: 360). All options presented in this proposed dictionary design are tailored to the needs of the users so that they can find the best solutions to their lexicographical problems. Such a dictionary can be called a proper Internet dictionary, because it takes advantage of technological features to provide a lexicographical solution in such a well-planned way that users can solve their lexicographical problems efficiently and effectively. If this proper Internet dictionary is to be called a real Internet dictionary, in addition to providing the solution in a well-planned way, it should also be made from scratch, not from an available printed version, and it should be updated regularly, according to recent developments and inputs from users.

\section{Conclusion}

The discussion in this article shows that the current Internet finance dictionaries have not utilized the Internet technological features well in designing their access routes. Some Internet finance dictionaries only use access routes similar to those in printed dictionaries, so they can simply be called meagre Internet dictionaries. Other Internet finance dictionaries utilize so many technological features that users still incur high lexicographical information costs. Such dictionaries can be called extravagant Internet dictionaries owing to the fact that they carelessly use too many technological features.

The discussion also shows that using a theoretical approach such as the modern theory of lexicographical functions results in better designs for future Internet finance dictionaries. Knowing the specific types of potential user, user situation, and user need will enable lexicographers to create dictionaries which can provide better and more focused assistance to cover the needs of the users. Therefore, modern lexicographers should always aim at creating state-of-theart dictionaries which can be categorized as proper Internet dictionaries or real Internet dictionaries. 


\section{References}

Andersen, B. and S. Nielsen. 2009. Ten Key Issues in Lexicography for the Future. Bergenholtz, H., S. Nielsen and S. Tarp (Eds.). 2009. Lexicography at a Crossroads: 355-365. Bern: Peter Lang.

Atkins, B.T.S. and M. Rundell. 2008. The Oxford Guide to Practical Lexicography. Oxford/New York: Oxford University Press.

Bergenholtz, H. and M. Johnsen. 2007. Log Files Can and Should Be Prepared for a Functionalistic Approach. Lexikos 17: 1-20.

Bergenholtz, H. and S. Nielsen. 2006. Subject-field Components as Integrated Parts of LSP Dictionaries. Terminology 12(2): 281-303.

Bergenholtz, H. and S. Tarp. 2003. Two Opposing Theories: On H.E. Wiegand's Recent Discovery of Lexicographic Functions. Hermes, Journal of Linguistics 31: 171-196.

Bogaards, P. 1999. Access Structures of Learners' Dictionaries. Herbst, T. and K. Popp (Eds.). 1999. The Perfect Learners' Dictionary (?): 113-130. Tübingen: Niemeyer.

Carew, E. 1996. The Language of Money. http://www.anz.com/edna/dictionary.asp. [Accessed 15 December 2009].

De Schryver, G.-M. 2003. Lexicographers' Dreams in the Electronic-Dictionary Age. International Journal of Lexicography 16(2): 143-199.

http://www.financial-dictionary.thefreedictionary.com [Accessed 15 December 2009].

http://www.investopedia.com/dictionary/default.asp [Accessed 15 December 2009].

Morgenson, G. and C.R. Harvey. 2002. The New York Times Dictionary of Money and Investing. http://www.duke.edu/ charvey/Classes/wpg/glossary.htm. [Accessed 15 December 2009].

Nielsen S. 1999. Mediostructures in Bilingual LSP Dictionaries. Lexicographica, International Annual for Lexicography 15: 90-113.

Nielsen, S. 2008. The Effect of Lexicographical Information Costs on Dictionary Making and Use. Lexikos 18: 170-189.

Nielsen, S. and L. Mourier. 2005. Internet Accounting Dictionaries: Present Solutions and Future Opportunities. Hermes, Journal of Linguistics 34: 83-116.

Tarp, S. 1994. Funktionen in Fachwörterbüchern. Bergenholtz, H. and B. Schaeder (Eds.). 1994. Fachlexikographie. Fachwissen und seine Repräsentation in Wörterbüchern: 229-246. Forum für Fachsprachen-Forschung 23. Tübingen: Gunter Narr.

Tarp, S. 1998. Leksikografien på egne ben. Fordelingsstrukturer og byggedele i et brugerorienteret perspektiv. Hermes, Journal of Linguistics 21: 121-137.

Tarp, S. 2008. Lexicography in the Borderland between Knowledge and Non-knowledge. General Lexicographical Theory with Particular Focus on Learner's Lexicography. Lexicographica. Series Maior 134. Tübingen: Niemeyer. 